\title{
ORGANIZATION OF DUAL TRAINING THROUGH THE STEAM APPROACH IN HIGHER EDUCATION
}

\author{
Shoxrux Razzoqovich Turdiyev
}

Phd, Associate Professor, Karshi Engineering Economics Institute, Uzbekistan

\section{ABSTRACT}

This article is an important role in the organization of dual education. Steam education is better than a number of traditional teaching, which is clarified by the unique features of dual teaching, ie the concepts such as the unification of practical experience and theoretical training.

KEYWORDS:- Dual Education, Steam-Education, Steam-Support, Design, Engineering, Engineering, Integration, Professional Activities, Creative Thinking, Practice.

\section{INTRODUCTION}

Article 15 of the Law of the Republic of Uzbekistan on the new Education Law of the Republic of Uzbekistan has provided 8 forms of education, which is one of the forms of education [1]. In carrying out this training, the decision of the Cabinet of Ministers dated March 29, 2021 № 163 "on measures for the organization of dual education in Professional education" was adopted and began to be used in professional education processes starting from 2021/2022 academic year[2]. The idea we offer is to introduce the step-by-step dual education to higher education institutions.

Literature review. Dual training has long been present in the pedagogy, proving itself in the world in different countries. The main directions of application of dual education are higher and professional education. Although Dual education is recently incoming in Uzbekistan, it is already a very popular approach to train new professional staff. A distinctive feature of the dual teaching is the union of practical experience and theoretical training. It is the such a new approach in the system of professional education provides quality preparation of future highly qualified specialists [3].

Scientific novelty of the article. One of the instruments of investment attractiveness and competitiveness of the territories through training of high-tech production requirements is this dual education system, which is the coordinated interaction of teaching and industrial areas in training specialists and the high level of graduates is to provide employment.

Analysis and results. Forms of dual education are mainly used in areas such as engineering, economy and social security. At the same time, specialty, like specialty, also cover machinery, engineering, construction, real estate industry, tourism management and social management. 
Germany is the leader in the world's national education, in which the developer system of vocational education, the active training and personnel training, is distinguished by the active participation of business. The experience of this country will serve as a model for the whole of European Union [4]. We can see the advantages and shortcomings of dual learning in Table 1 below.

\section{Table.1}

\begin{tabular}{|c|c|}
\hline \multicolumn{2}{|c|}{ Advantages and disadvantages of dual education } \\
\hline Advantages of Dual Education & Disadvantages of Dual Education \\
\hline $\begin{array}{c}\text { The practical section is carried out not } \\
\text { only in the workshops and in the fields } \\
\text { of educational institutions, but also in } \\
\text { enterprises. }\end{array}$ & $\begin{array}{c}\text { The quality of education with teaching } \\
\text { motivations at the enterprise may } \\
\text { decrease. }\end{array}$ \\
\hline $\begin{array}{c}\text { The content of working programs is } \\
\text { agreed among educational institutions } \\
\text { and employers. }\end{array}$ & $\begin{array}{c}\text { Work programs do not always comply } \\
\text { with the seasonal sequence of work } \\
\text { performed in production. }\end{array}$ \\
$\begin{array}{c}\text { educational institution and the } \\
\text { enterprise can arise and develop. }\end{array}$ & $\begin{array}{c}\text { The educational institution may not } \\
\text { always be able to deliver the necessary } \\
\text { training materials for enterprises. }\end{array}$ \\
\hline $\begin{array}{c}\text { When the graduate is employed, the } \\
\text { knowledge can immediately apply can } \\
\text { apply the accurate descriptions, as well } \\
\text { as the same level of preparation. }\end{array}$ & $\begin{array}{c}\text { It is not enough to teach enterprises - as } \\
\text { a result of which there are no learning } \\
\text { The continuous change in the } \\
\text { educational institution and the }\end{array}$ \\
\hline
\end{tabular}




\section{Crossref doi) 81 Google}

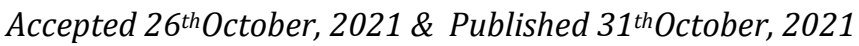

$$
\begin{aligned}
& \text { enterprise helps good motivation and } \\
& \text { the production process is not strictly } \\
& \text { interrupted. }
\end{aligned}
$$

Advantages and disadvantages of dual education. In the organization of dual education, the need to establish Steam - Educational Organizations. (Fig. 1).
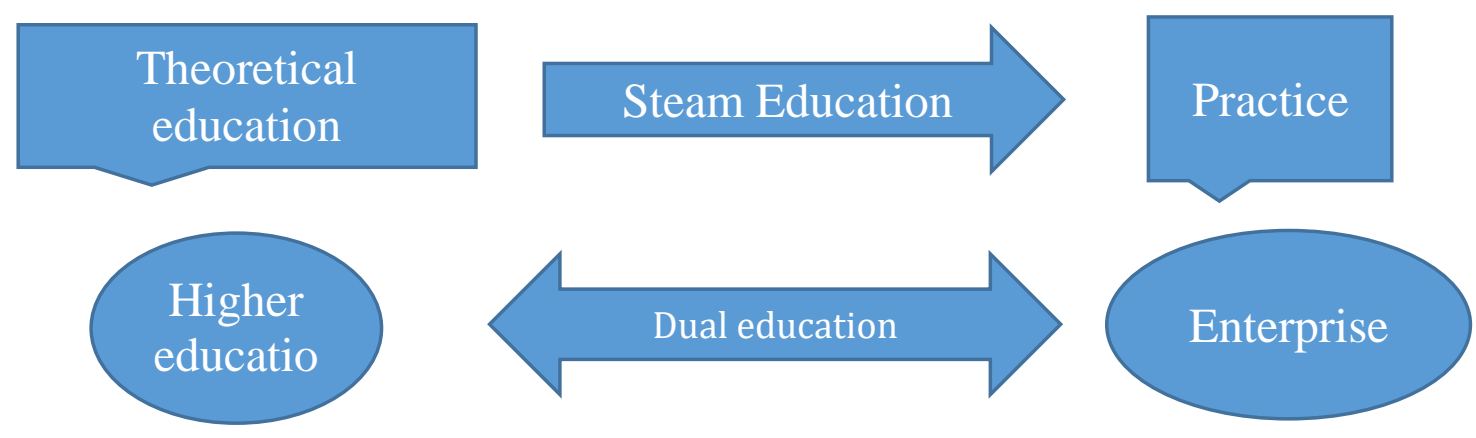

Figure 1. Use Steam training in organizing Dual education.

The term stem was first included in the School Program in the United States, and students are aimed at developing their competence in scientific and technical directions. This route was later expanded and additional letters were included in the term. In particular, he began to call Stream by adding "Robotic robotot technology or" A "- by adding Art art. This concept was adopted as a inovational approach to education. The most popular example of the STEAM approach is the Massachusetts Institute of Technology. The motto of this famous university is "mind and hand". The Massachusetts Institute of Technology has developed STEAM courses and even opened STEAM training centers in some educational institutions[6].
Steam helps students develop the following important features and skills. Comprehensive understanding of problems, understand creative thinking, engineering approach, understanding, understanding, and use design foundations, and others. Technology of Steam Education is carried out through the methods of constructucts, design and modeling and on its basis lies the theoretical knowledge, as well as artistic research. This training unites students closely knowledge of theoretical and practices. The Steam-approach allows students to open new concepts, creative thinking, understanding, understanding, logical observation, to understand the mutual observation, the theory and the interaction in theory and practice [5]. 
As a number of traditional education of Steam education, we list them:

First, integrate education on topics, not in the academic disciplines. Interdisciplinary communication and design method is combined in Steam-Education, on the basis of which natural sciences are lies on technology, engineering creativity and mathematics. Preparations for professional activities related to engineering are carried out;

Second, use scientific and technical knowledge that students have received in real life. With the help of practical classes, students are shown in real life of scientific and technical knowledge. In each lesson, students develop, build and develop modern industry models.

Third, the third critical thinking skills and solving problems. Steam-program develops the skills to solve critically thinking and problems that need to overcome the difficulties they face in their daily lives.

Fourth, an increase in a feeling of trusting in its own strength. Students learn to eliminate the problems of the upcoming professional disuses during their education during their education, build a bridge and approach the purpose every time you run a model. Will improve the model after each test. In the end, they achieve the goal of overcome all problems with their own forces. It means inspiration, victory, and joy for students. After every victory, they are more confident in their forces.

Fifth, active communication and work in groups. The STEAM-program is different from active communication and work. During the talks, a free environment will be created to express its opinion and debate its opinion. They learn to speak and make a presentation. Students always remember the workout well if they are always referring to teachers and each other and actively participate in the process.
Sixth, development of interests in specialization and general professional subjects. The task of Steam education in higher education is to increase students' interest in specialty and general professional subjects. Since the Steam training is very speaker and fun, students do not bore during the training and do not feel how time the time is.

Seventth, creative and innovative approach to projects. Steam-school consists of six stages: assignment, discussion, design, construction, testing and development. These stages are the basis of a systematic design approach.

The eighth, a bridge between education and professional activity. Steam's knowledge will be needed in the professions of engineers, analysts, computer systems, engineers, engineers, and robotechnics engineers, engineers, engineers, engineers, and engineers, and engineers, and engineers, engineers, and engineers, and engineers, and engineers, and engineers, and engineers, apparities.

Ninth, preparing students for technological innovative life. Steam-skills are questioning students' skills to work with fast-developing equipment and technology.

Ten, software applications will be used in the implementation of independent training in higher education curricula.

Conclusion. Conclusion Simultaneously, the introduction of modern science achievements in practice.

\section{REFERENCES}

1. Law of the Republic of Uzbekistan "on education". T.2020y.

2. Decree of the Cabinet of ministers № 163 of March 29, 2021 "on measures for the organization of dual education in Professional education". 
CURRENT RESEARCH JOURNAL OF PEDAGOGICS 2(10): 215-219

October 2021 DOI: https://doi.org/10.37547/pedagogics-crjp-02-10-39

ISSN 2767-3278

(C)2021 Master Journals

Crossref do) 81 Google

Accepted 26 ${ }^{\text {th }}$ October, 2021 \& Published $31^{\text {th }}$ October, 2021

3. Turdiyev SH. Forming Innovative Abilities of Students in Engineering and Research. //Eastern European Scientific Jornal. 2017. №1 DOI10.12851/EESJ201701.P-163-168.

4. Turdiyev SH. The role of practical classes and methods to implement them when promoting mathematical problems in technical university //European Journal of Research and Reflection in Educational Sciences.-Great Britain.: 2016.-№2. P-3640.

5. Turdiyev SH., Shadiev R. On questions of particularities of teaching mathematics in technical higher education institutions (HEI). Austrian Journal of Humanities and Social Sciences № 9-10.Vienna , 2014.pp 141-144.

6. Петров Ю.Н. Дуальная система инженерно-педагогического образования - инновационная модель современного профессионального образования. Н. Новгород, 2009. 280 с.

7. Дуальное образование в Ярославской области: Организационный этап: Методическое пособие / В.Ю. Выборнов и др.; под. ред. В.Ю. Выборнова. Ярославль: ГОАУ ЯО ИРО, 2014. 155 с.

8. https://www.integer.uz/steam

9. http://nambiolog.zn.uz/files/STEAMtalimi. 